\title{
Neurologic complications of acute hepatitis E virus infection
}

Paolo Ripellino, MD, Emanuela Pasi, MSc, Giorgia Melli, PhD, MD, Claudio Staedler, MD, Monserrat Fraga, MD, Darius Moradpour, MD, Roland Sahli, MSc, PhD, Vincent Aubert, MSc, PhD, Gladys Martinetti, MSc, Florian Bihl, MD, Enos Bernasconi, MD, Benedetta Terziroli Beretta-Piccoli, MD, Andreas Cerny, MD, Harry Roland Dalton, MD, PhD, Cinzia Zehnder, MSc, Barbara Mathis, MSc, Chiara Zecca, MD, Giulio Disanto, MD, PhD, Alain Kaelin-Lang, MD, PhD, and Claudio Gobbi, MD

Neurol Neuroimmunol Neuroinflamm 2020;7:e643. doi:10.1212/NXI.0000000000000643 e643

\section{Abstract}

\section{Objective}

To assess the prevalence and clinical features of neurologic involvement in patients with acute hepatitis E virus (HEV) infection in Southern Switzerland.

\section{Methods}

Among 1,940 consecutive patients investigated for acute hepatitis E, we identified 141 cases of acute of $\mathrm{HEV}$ infection (anti-HEV immunoglobulin $\mathrm{M}$ and immunoglobulin $\mathrm{G}$ both reactive and/or HEV RNA positive) between June 2014 and September 2017. Neurologic cases were followed up for 6 months. We compared patients with and without neurologic symptoms.

\section{Results}

Neurologic symptoms occurred in 43 acute HEV cases (30.4\%) and consisted of neuralgic amyotrophy (NA, $\mathrm{n}=15,10.6 \%)$ and myalgia $(\mathrm{n}=28,19.8 \%)$. All NA cases were immunocompetent. Men had higher odds (OR = 5.2, CI 1.12-24.0, $p=0.03$ ) of developing NA after infection with $\mathrm{HEV}$, and in 3 couples simultaneously infected with $\mathrm{HEV}$, only men developed NA. Bilateral involvement of NA was predominant (2:1) and occurred only in men. Seven NA cases were viremic (all genotype 3), but HEV was undetectable in their CSF. In the acute phase of NA, 9 patients were treated with intravenous immunoglobulin and 4 with prednisone, reporting no side effects and improvement in pain and strength. Myalgia occurred both without $(\mathrm{n}=16)$ or with $(\mathrm{n}=12)$ concomitant elevated serum creatinine kinase. Seven cases with myalgia in the shoulder girdle did not have muscle weakness ("forme fruste" of NA).

\section{Conclusions}

Neurologic symptoms occurred in one-third of acute HEV infections and consisted of NA and myalgia. NA seems to occur more frequently in men infected by HEV and has a predominant (but not exclusive) bilateral involvement.
Correspondence

Dr. Ripellino

pao.ripe@hotmail.it
MORE ONLINE

Q Videos

From the Department of Neurology (P.R., G.M., C.S., C.Z., G.D., A.K.-L., C.G.), Neurocenter of Southern Switzerland, Lugano, CH; Laboratory of Microbiology EOLAB (E.P., G.M.), Bellinzona, CH; Faculty of Biomedical Sciences, USI (G.M., C.Z., A.K.-L., C.G.), Lugano, CH; Division of Gastroenterology and Hepatology, Lausanne University Hospital (M.F., D.M.), Lausanne, CH; Institute of Microbiology, Lausanne University Hospital (R.S.), Lausanne, CH; Laboratory of Immunology, Lausanne University Hospital (V.A.), CH; Department of Hepatology, Hospital of Bellinzona (F.B.), CH; Division of Infectious Diseases (E.B.), Hospital of Lugano, CH; Epatocentro Ticino (B.T.B.-P., A.C.), Lugano, CH; Queens Park (H.R.D.), London, UK; Synlab Ticino (C.Z.), Bioggio, CH; and Unilabs Ticino (B.M.), Lugano, $\mathrm{CH}$. 


\section{Glossary}

ALT = alanine aminotransferase; ANA = antinuclear antibodies; $\mathbf{C K}=$ creatinine kinase $; \mathbf{G B S}=$ Guillain-Barré syndrome; HEV = hepatitis E virus; IFN = interferon; IVIg = intravenous immunoglobulin; NA = neuralgic amyotrophy.

Hepatitis E virus (HEV) is one of the most common causes of acute hepatitis in the world, ${ }^{1}$ and its incidence is increasing. ${ }^{2}$ In developed countries, infection is mainly due to ingestion of contaminated raw meat of pork or game. ${ }^{1}$ In Switzerland, HEV seroprevalence is estimated to be approximately $20 \%$ in healthy blood donors, depending on age and geographical area, being the highest $(35 \%)$ in Southern Switzerland. ${ }^{3}$

Most cases of HEV infection in humans are asymptomatic, ${ }^{1}$ whereas some lead to acute hepatitis and only a minority to extrahepatic manifestations. ${ }^{4,5}$ Intriguingly, the most common extrahepatic features of HEV infection are neurologic diseases. ${ }^{6-8}$ These mainly include acute dysimmune neuropathies such as neuralgic amyotrophy (NA) ${ }^{9}$ and GuillainBarré syndrome (GBS), ${ }^{10}$ Bell palsy, ${ }_{11}^{11}$ myalgia/myositis, ${ }^{12}$ encephalitis, ${ }^{13}$ transverse myelitis, ${ }^{14}$ and, more recently, myasthenia gravis. ${ }^{15}$

Recent cohort and case-control studies (mainly, but not exclusively from Europe) showed that 5\%-11\% of GBS cases ${ }^{10,16-18}$ and $10 \%$ of patients with $\mathrm{NA}^{9}$ were infected by HEV at disease onset. Recent HEV infection was found in $2.4 \%$ of consecutive nontraumatic neurologic patients. ${ }^{19}$ On the other hand, a variable proportion of confirmed cases of acute HEV infection (between 5\% and 22\%, depending on the geographical area and study type) have been reported to develop neurologic symptoms. ${ }^{20-22}$

\section{Objectives}

The aim of our study was to further explore the relationship between HEV infection and neurologic complications in a well-defined geographical area.

\section{Methods}

\section{Subjects}

We prospectively studied consecutive adult patients diagnosed with acute HEV infection between June 1, 2014, and September 30, 2017. The study was conducted in Ticino, a region of Southern Switzerland with a population of approximately 350,000 inhabitants. During the study period, all laboratories in Ticino centralized the testing of samples for HEV to the Laboratory of Microbiology EOLAB, Bellinzona.

\section{Aims}

1. To assess the prevalence of neurologic manifestations occurring in subjects with acute HEV infection living in Ticino
2. To compare characteristics of patients with acute HEV infection with and without neurologic involvement and clinically characterize these neurologic manifestations

\section{Inclusion criteria}

The diagnostic criteria for acute HEV infection were detection of ${ }^{9,10}$

1. serum anti-HEV immunoglobulin $M$ and anti-HEV immunoglobulin $\mathrm{G}$ both reactive and/or

2. HEV RNA+ documented in serum and/or feces by reverse transcription polymerase chain reaction

Subjects with false-positive serologic results (low HEV IgM positivity, not confirmed by a repeated serologic test after 1 month) or with any other concomitant acute infections or vaccinations and patients with any other causes of acute hepatitis were excluded.

\section{Clinical data}

Demographic (age and sex) and clinical data (immunosuppression status, alanine aminotransferase $[\mathrm{ALT}]$, and bilirubin levels) were collected. All patients were screened for neurologic symptoms and/or signs by the treating physician and referred for neurologic evaluation at the Neurocenter of Southern Switzerland, Lugano, on suspicion of neurologic involvement. Such patients underwent a full neurologic examination and had a series of investigations to exclude concomitant infections (hepatitis A virus, hepatitis B virus, hepatitis C virus, human immunodeficiency virus, cytomegalovirus, Epstein-Barr virus, Borrelia burgdorferi, and Treponema pallidum) and additional tests as clinically appropriate (antinuclear antibodies [ANA], antidouble strand DNA antibodies, extractable nuclear antigen antibodies, antineutrophil cytoplasmic antibodies screening, antiganglioside antibodies tests, lumbar puncture, brachial plexus, brain and spinal MRI, and electrodiagnostic studies) and were all followed up for at least 6 months thereafter.

NA was defined by van Eijk et al. ${ }^{23}$ and GBS according to NINDS criteria. ${ }^{24}$ Myalgia was defined as pain in the muscles present at rest, neither preceded by trauma or physical exercise nor triggered by medication, with a minimal intensity of $5 / 10$ on the visual analogue scale, independent of the creatinine kinase (CK) level.

\section{Virologic analyses}

Sera from patients with suspected HEV infection were tested for HEV IgG and IgM with Dia.Pro kits (Diagnostic Bioprobes srl, Italy). Real-time quantitative HEV RNA reverse transcriptase polymerase chain reaction and HEV genotype determination were performed according to Fraga et al. ${ }^{25}$ 


\section{Statistical analysis}

Continuous variables were described by median with interquartile ranges and categorical variables by counts and percentages. Age, sex, immunosuppression status, and liver function parameters were tested for potential association with neurologic disease status using logistic regression with OR and $95 \%$ CI estimation. Statistical significance was set at 2 -sided $p$ values $<0.05$. Data were analyzed with the $\mathrm{R}$ statistics package (r-project.org/).

\section{Ethical aspects}

The study was approved by the local Ethics Committee of Ticino (CE 2932), and written informed consent was obtained from the participants in the study. Authorization has been obtained for disclosure of any recognizable person in videos.

\section{Data availability}

Anonymized data that are not published in the current study will be shared on request from any qualified investigator.

\section{Results}

Among 1,940 patients investigated for acute HEV infection, 150 cases were identified (figure 1). Nine were excluded because of false-positive serologic results $(n=5)$, concomitant CMV infection ( $n=3$; one of these cases had GBS), or recent vaccination $(\mathrm{n}=1$; this patient had encephalomyelitis). The final analysis included 141 HEV IgM- and IgG-positive cases; 35 (25\%) were also HEV RNA positive, and all were HEV genotype 3 when sequencing was successful.

Reasons for HEV testing were acute hepatitis with $(\mathrm{n}=55$, $39 \%)$ or without $(\mathrm{n}=34,24 \%)$ jaundice, unexplained increased liver enzyme resulting from screening of clinically asymptomatic patients $(\mathrm{n}=7,5 \%)$, acute kidney failure $(\mathrm{n}=2$, $1 \%)$, and neurologic symptoms $(n=43,30.4 \%)$ consistent

Figure 1 Flowchart of the study design

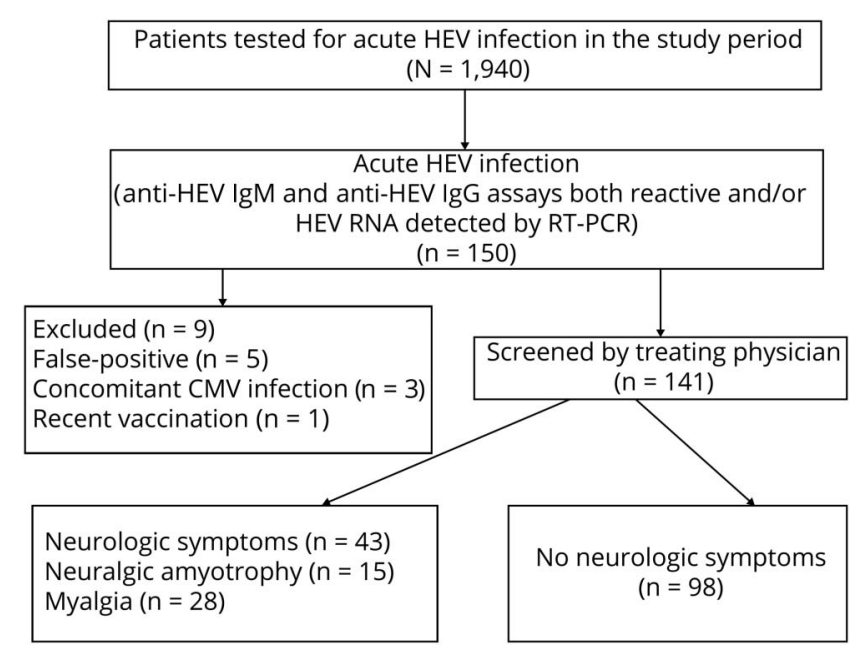

with NA $(n=15,10.6 \%)$ or myalgia $(n=28,19.8 \%)$. Some of these cases have been reported in previous studies with different aims. ${ }^{25,26}$

Age, sex, immunosuppression status, ALT, and bilirubin levels of the overall cohort at onset are summarized in table 1 . The median age was 59 years, with a nonsignificant predominance of men ( $59 \%$ vs $41 \%)$. Compared with patients without neurologic manifestations, those with neurologic involvement were younger $(\mathrm{OR}=0.97$, CI $0.94-0.99, p=0.01)$. NA occurred more frequently in men $(\mathrm{OR}=5.2$, CI 1.12-24.0, $p=$ $0.03)$, whereas myalgia occurred less frequently in men $(\mathrm{OR}=$ 0.36 , CI $0.15-0.86, p=0.02$ ). We did not identify any differences in immunosuppression status, ALT, or serum bilirubin levels between patients with and without neurologic symptoms.

Within the group with neurologic complications, we observed 3 couples (husband and wife) simultaneously infected by $\mathrm{HEV}$, probably from a common food source. Although all husbands developed bilateral NA, their wives were asymptomatic $(\mathrm{n}=2)$ or had transient myalgia $(\mathrm{n}=1)$.

\section{Neuralgic amyotrophy}

NA cases appeared to cluster in rural areas (figure 2) and not in the city of Lugano, the most populated area $(70,000$ inhabitants).

Shoulder pain was often described as "like a knife penetrating muscles" and was severe enough to prompt patients to attend the emergency ward even in the middle of the night. Neurologic involvement in HEV-NA was bilateral (although asymmetrical) in 10 men and predominantly located in the upper plexus. ${ }^{26}$ Scapular winging from long thoracic nerve damage was a recurrent feature $(10 / 15,67 \%)$ observed at disease onset ${ }^{27}$ (figure 3A). In 3 cases, amyotrophy had a clear patchy distribution, suggesting that nerve damage occurred at the fascicular level $\mathrm{l}^{23,28}$ (figure 3B).

The laboratory and clinical data of the HEV-NA cases are summarized in table 2. None of the patients with HEV-NA were immunosuppressed at the time of infection. Lumbar puncture was performed in 6 of 10 NA cases with bilateral involvement. One patient with extended neurologic damage (involving the brachial plexus bilaterally, lumbosacral plexus, and trigeminal nerve) had an increased CSF cell count (55 cells $/ \mathrm{mcl}$ ) and protein level, whereas isolated albumincytologic dissociation was found in 2 other bilateral HEVNA cases.

Viral HEV RNA gt-3 was detected in the serum of 7 of 8 NA cases tested within 1 week from onset. In 5 of these, concomitant CSF was collected on the same day, but none contained HEV RNA. Serum immunofixation showed a monoclonal IgM peak $(\kappa$ or $\lambda$ ) in 5 bilateral NA cases tested in the acute phase, which disappeared within a few weeks. ANA antibodies were positive at low titer $(1 / 80-1 / 160)$ in 5 of 10 bilateral HEV-NA cases. 
Table 1 Study population characteristics

\begin{tabular}{|c|c|c|c|c|}
\hline & \multirow[b]{2}{*}{ All $(n=141)$} & \multicolumn{2}{|c|}{ Neurologic cases $(n=43)$} & \multirow{2}{*}{$\begin{array}{l}\text { Nonneurologic cases } \\
(n=98)\end{array}$} \\
\hline & & NA $(n=15)$ & Myalgia $(n=28)$ & \\
\hline Age (median) (IQR) & $59(48-70)$ & $51(45-61)$ & $53(43-62)$ & $60(49-73)$ \\
\hline Male & $83(59 \%)$ & 13 & 11 & 59 \\
\hline Female & $58(41 \%)$ & 2 & 17 & 39 \\
\hline Immunosuppression & 16 & 0 & 3 & 13 \\
\hline $\mathrm{ALT}^{\mathrm{a}}$ (median) (IQR) & $175(56-741)$ & $240(100-957)$ & $88(28-394)$ & 211 (57-938) \\
\hline Bilirubin $^{\text {a }}$ (median) (IQR) & $20(13-53)$ & $19(14-35)$ & $14(11-17)$ & $24(14-74)$ \\
\hline HEV RNA in serum (all gt3) & 35/64 tested & $7 / 12$ & $7 / 12$ & $24 / 40$ \\
\hline
\end{tabular}

Abbreviations: ALT = alanine aminotransferase (IU/L; normal < 50), bilirubin ( $\mu$ mol/L, normal <19); gt3 = genotype 3; HEV = hepatitis E virus; IQR = interquartile range; $\mathrm{NA}=$ neuralgic amyotrophy.

${ }^{a}$ At disease presentation.

Serum antiganglioside antibodies (GM1, GM2, GD1a, GD1b, and GQ1b) and anti-myelin-associated glycoprotein were negative in all bilateral HEV-NA cases.

Electrodiagnostic studies were performed within 1 month in all HEV-NA cases. Motor and sensory nerve conduction studies were normal, as previously reported by others. ${ }^{29}$ Needle electromyography showed in all cases in the acute phase a reduced (neurogenic) recruitment pattern in affected shoulder girdle muscles and also signs of acute denervation (fibrillation potentials and positive sharp waves) in 10 cases $(66 \%)$, which disappeared within 6 months.

Figure 2 Location of Ticino in Switzerland and geographical distribution of HEV-NA cases

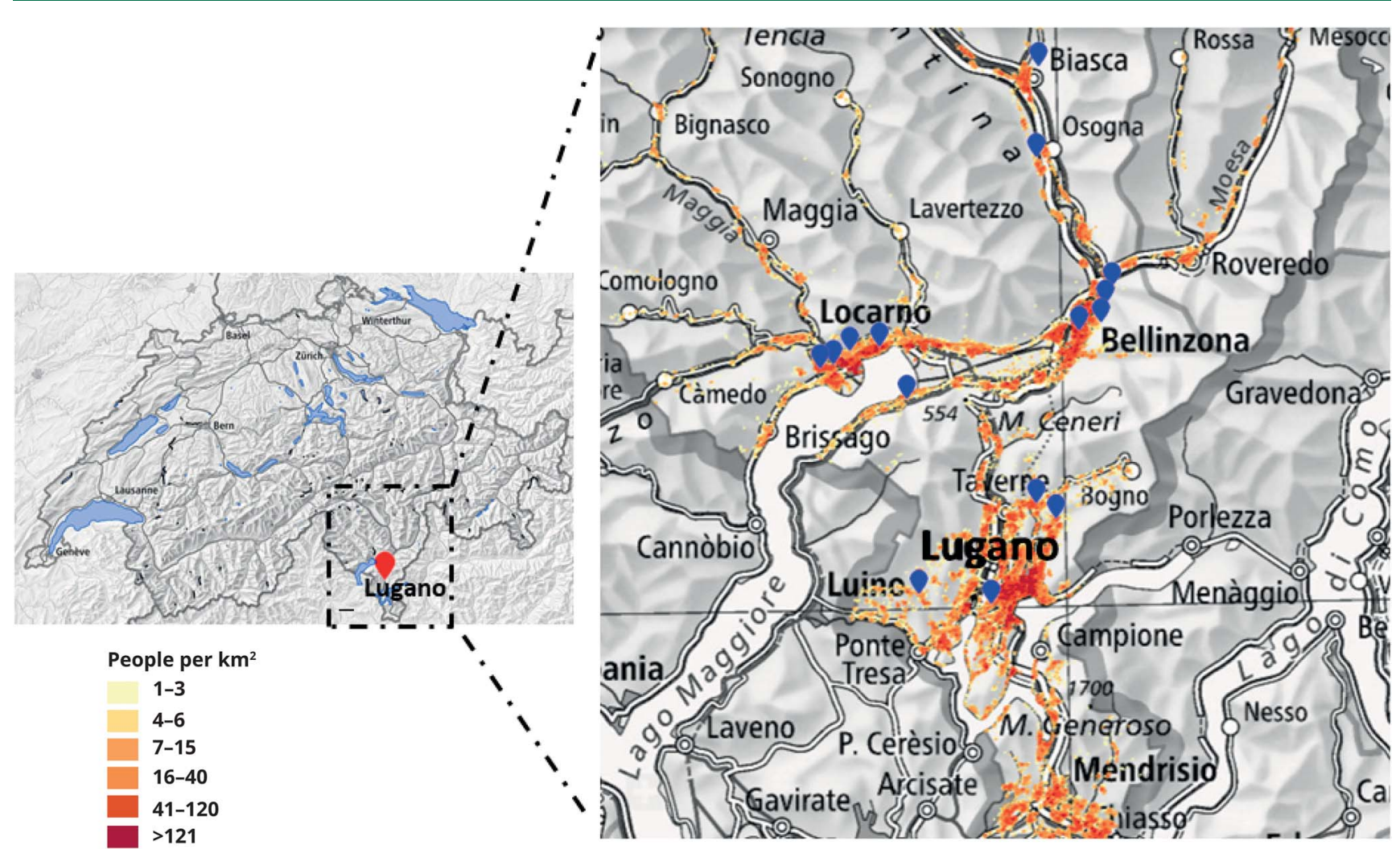

The residence of the 15 NA cases is approximated by blue dots. The population density in the area is shown in different colors in a red scale (legends on the left). Most of the cases were not located in urban but in rural areas (this map has been obtained from data of the Federal Office of Topography [Swisstopo]) $\mathrm{HEV}=$ hepatitis E virus; NA = neuralgic amyotrophy. 
Figure 3 Clinical picture of HEV-NA

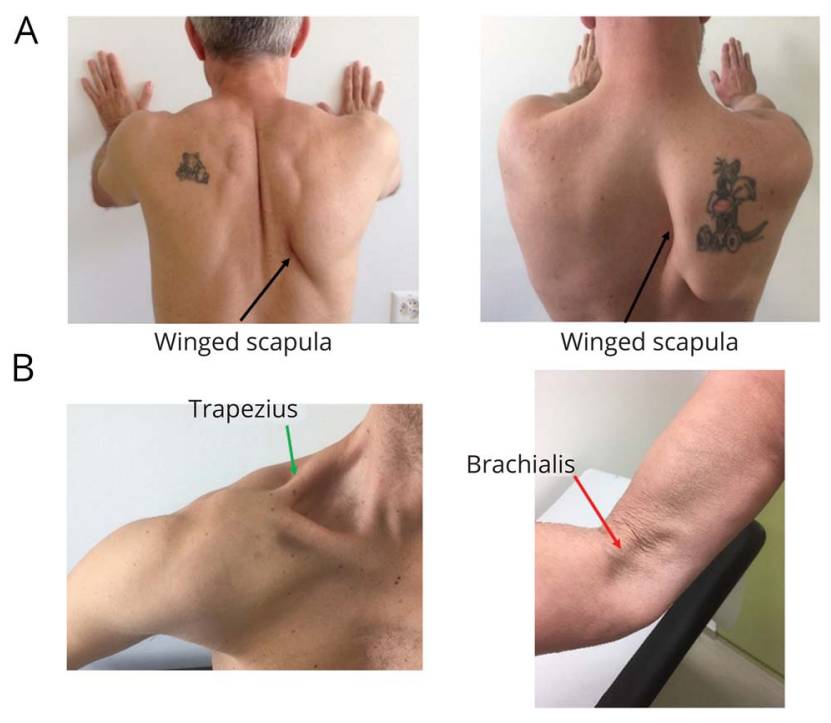

(A) In bilateral HEV-NA cases (above), winged scapula (black arrows) is recurrent and often asymmetrical. (B) In unilateral HEV-NA cases (below), amyotrophy is often very focal, affecting one muscle and sparing the neighboring muscle (left: involvement of the upper trapezius = green arrow, deltoid spared; right: brachialis muscle affected = red arrow, biceps brachii spared). HEV = hepatitis E virus; NA = neuralgic amyotrophy.

Two patients with unilateral HEV-NA did not receive any immunomodulatory treatment because they had minor weakness. Regarding the remaining HEV-NA cases, they were treated within 10 days from onset either with intravenous immunoglobulin (IVIg) $0.4 \mathrm{~g} / \mathrm{kg} / \mathrm{d}$ for 5 days in cases of bilateral involvement $(\mathrm{n}=9)$ or with oral prednisone $60 \mathrm{mg} / \mathrm{d} \times 7$ days, with tapering in 7 days in cases of unilateral weakness $(n=4)$, as previously reported in a retrospective study. ${ }^{30}$

All patients with HEV-NA receiving these immunomodulatory treatments reported both reduction in pain and improvement in shoulder mobility and strength within 7-10 days (video 1 for steroids, video 2 for IVIg). All patients received supportive physiotherapy over the course of their illness. Four cases received pregabalin $150 \mathrm{mg} / \mathrm{d}$ for $2-3$ months to treat neuropathic pain. Regarding long-term recovery, 3 heavy manual workers with bilateral HEV-NA had to stop their job for more than 6 months because of early fatigability of affected arms.

\section{Myalgia}

Myalgia occurred in 28 cases, both with $(\mathrm{n}=12)$ and without ( $n=16)$ concomitant elevated $(>200 \mathrm{U} / \mathrm{L})$ serum CK. The highest $\mathrm{CK}$ value in our patients was $4.100 \mathrm{U} / \mathrm{L}$. The pain was often unbearable, was more intense in the night, and had clear neuropathic features characterized by "burning," "squeezing," "electric shock," and "lancinating" sensations (DN4 score $>4)^{31}$

Muscle pain disappeared spontaneously after 2 or 3 weeks in all cases and was either diffuse $(n=21)$ or located selectively in the shoulder girdle ("forme fruste" of NA, $n=7$ ). We defined "forme fruste" of patients with NA with severe, neuropathic shoulder pain (unilateral or bilateral) lasting not more than 72 hours, which was not followed by limb weakness. Three of these patients with "forme fruste" of NA had an increased CK level (up to $500 \mathrm{U} / \mathrm{L}$ ), and 5 underwent electromyography studies which were normal. None of these patients received brachial plexus MRI or muscle biopsy.

\section{Discussion}

The findings of our study suggest that neurologic symptoms in patients with acute HEV infection may be more common than previously estimated. Retrospective studies organized in hepatological settings described neurologic illness in $5 \%-7.5 \%$ of patients presenting with clinical or subclinical hepatitis. ${ }^{4,20,21}$ However, more recent findings from a prospective study performed in France ${ }^{22}$ showed that $22 \%$ of immunocompetent HEV cases had neurologic symptoms, which is more in line with our findings.

There are several possible reasons to explain why we observed so many cases of neurologic injury associated with HEV. One possibility is that neurologic damage could be related to the neurotropism of the circulating HEV viral strains in Southern Switzerland. An alternative explanation could be that the local awareness about HEV infection prompted physicians to test for HEV cases with unexplained abnormally high serum aminotransferases, especially in case of pain. Finally, it is also likely that in previous studies, myalgia was not identified or classified as a neurologic symptom. This is especially true for the "forme fruste" of $\mathrm{NA}^{26}$ an entity that is currently overlooked also by neurologists because of late (or absent) referral.

None of our neurologic cases was jaundiced, and in most the liver function test abnormality was modest (ALT $<1,000 \mathrm{IU} /$ L). In particular, NA appeared to be strongly associated with HEV, occurring in $11 \%$ of acute HEV cases (especially in men) with a predominant (2:1) bilateral involvement. It is noteworthy that all 12 bilateral NA cases diagnosed at the Neurocenter in Lugano in the past 3 years were men with acute HEV infection. These findings confirm previous observations that the predominant clinical phenotype of HEV-associated NA is that of bilateral involvement of the brachial plexus. ${ }^{26}$

It is currently unclear why after exposure to the same infectious agent individuals develop different clinical manifestations. We identified sex as a possible risk factor because men with HEV had higher odds for NA. Our observation of 3 couples infected simultaneously with HEV is similar to a case report $^{32}$ more than 30 years ago, even before HEV discovery. Within an Italian family, 3 members simultaneously developed bilateral NA 1 week after a short fever, but the 2 brothers developed the full picture of NA (with scapular 
Table 2 Clinical features of HEV-related NA

\begin{tabular}{|c|c|c|c|}
\hline HEV-NA & Total $n=15$ & Bilateral $\mathbf{n}=10$ & Unilateral $\mathbf{n}=\mathbf{5}$ \\
\hline Age (median) (IQR) & $51(61-45)$ & 58 & 49 \\
\hline Male & $13(86 \%)$ & 10 & 3 \\
\hline Female & $2(14 \%)$ & 0 & 2 \\
\hline Hospitalization & 12 & 7 & 5 \\
\hline NRS $^{a}$ (median) at onset & $8(9.5-8)$ & 8 & 10 \\
\hline $\begin{array}{l}\text { EMG spontaneous activity (fibrillations, positive waves) } \\
\text { at } 1 \text { month }\end{array}$ & $10(67 \%)$ & 6 & 4 \\
\hline $\begin{array}{l}\text { HEV RNA + (serum })^{\text {b }} \\
\text { All gt-3 }\end{array}$ & 7 & 7 & 0 \\
\hline HEV RNA+ $(\text { CSF })^{c}$ & 0 & 0 & n.a. \\
\hline Lumbar puncture & 6 & 6 & 0 \\
\hline CSF WBC $>10 / \mathrm{mm} 3$ & $1 / 6$ & $1 / 6$ & n.a. \\
\hline CSF protein increase & $3 / 6$ & $3 / 6$ & n.a. \\
\hline $\mathrm{ALT}^{\mathrm{a}}$ (median) & $240(100-957)$ & 579 & 178 \\
\hline ALP $^{a}$ (median) & $126(80-174)$ & 126 & 128 \\
\hline Bilirubin $^{a}$ (median) & $19(14-35)$ & 52 & 13 \\
\hline $\mathrm{GGT}^{\mathrm{a}}$ (median) & $144(39-203)$ & 178 & 55 \\
\hline ANA positivity & 5 & 5 & 0 \\
\hline ENA positivity & 0 & & \\
\hline Antiganglioside antibodies & 0 & & \\
\hline IgM monoclonal peak in serum & 5 & 5 & 0 \\
\hline IVIg $0.4 \mathrm{~g} / \mathrm{kg} \times 5 \mathrm{~d}$ & 9 & 8 & 1 \\
\hline Oral prednisone $60 \mathrm{mg} / \mathrm{d} \times 7 \mathrm{~d}$, tapering in $7 \mathrm{~d}$ & 3 & 1 & 2 \\
\hline No immunomodulatory treatment & 2 & 0 & 2 \\
\hline \multicolumn{4}{|c|}{ 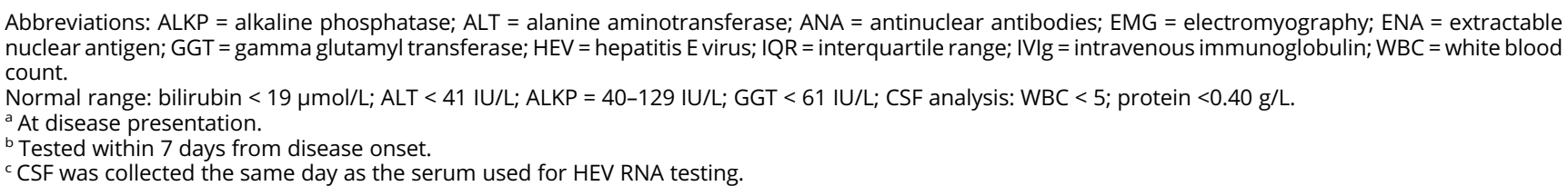 } \\
\hline
\end{tabular}

winging), whereas the mother suffered only from pain and had no weakness. Moreover, larger epidemiologic studies ${ }^{26}$ have shown that NA occurs more commonly in men (ratio 2: 1 ), and also in a recent French study, ${ }^{22} 5$ of 6 HEV-NA cases were men. The reason(s) why HEV-associated NA is more common in men is unclear, but sex hormones are known to influence innate ${ }^{33}$ and adaptive ${ }^{34,35}$ immune response during viral infection. The immune response to virus is regulated by interferons (IFNs), and IFN treatment can induce bilateral $\mathrm{NA}^{36}$

Regarding the host immune status, another factor that could potentially influence clinical presentation, it is important to note that all our 15 HEV-NA cases were immunocompetent.
When tested within 1 week from onset, 7 of 8 HEV-NA cases in our cohort were viremic, as previously described. ${ }^{9,20,21,26}$ By contrast, HEV is much less commonly found in the CSF, and in the literature, there are only 2 reported NA cases where HEV RNA has been demonstrated in the CSF. ${ }^{37,38}$ None of the 5 patients with NA who were viremic and received the lumbar puncture on the same day of serum collection showed HEV RNA in the CSF. Taken together, these data suggest that HEV is cleared very early in the CSF and/or that neurologic injury is mediated by mechanisms more complex than direct viral in vasion, e.g., through immune-mediated mechanisms. Recent studies showed that intrathecal synthesis of anti-HEV IgM can occur in HEV-NA cases. ${ }^{38}$ Although none of our patients with NA or myalgia underwent a biopsy, it is tempting to speculate 
that antibody/immunocomplexes deposition in the peripheral nerve and muscle tissues might contribute to neurologic damage. Similar mechanisms have previously been shown to be operative in cryoglobulinemia ${ }^{39}$ and other extrahepatic complications related to HEV. ${ }^{40}$ Unfortunately, in our study, cryoglobulins were not tested, so this hypothesis remains speculative.

According to our model of immune-mediated pathogenesis, we treated patients with NA in the acute phase with IVIg or steroids. Both treatments were always discussed with the hepatologist and tailored for each patient based on safety reasons (mainly the viremic state) and individual comorbidities (e.g., diabetes). We chose IVIg for bilateral cases because these patients were usually viremic (7/10), and we wanted to avoid worsening of viral replication/hepatitis by using highdose steroids. We instead preferred oral steroids for unilateral cases who were usually referred with a longer delay and were never viremic $(0 / 5)$. Treatment of patients with HEV-NA was however beyond the scope of this study, and no firm conclusions can be drawn from our observational study. However, it is worthwhile to note that all patients reported improvement of neuropathic pain, shoulder girdle muscle strength, and scapular dyskinesia within 7-10 days (videos 1 and 2) and that both IVIg and steroids were well tolerated. None of the viremic HEV-NA cases developed chronic HEV infection or experienced an increase in transaminase levels.

Regarding GBS, we excluded 2 cases of GBS who were reactive for both HEV IgM and IgG because they did not fulfill our inclusion criteria. The first of these patients had concomitant CMV infection, as reported by other authors, ${ }^{18}$ raising the question whether these observations were because of only crossreactivity or true co-occurrence of infections. Our second case of HEV GBS was excluded only because the diagnosis was made 3 months after study termination. This was an 80-yearold woman with an axonal form (AMSAN) of GBS. She developed acute tetraparesis, bilateral facial diplegia, and bulbar symptoms with a need for tracheotomy and assisted ventilation (GBS disability scale $=5$ ). She received 2 cycles of intravenous immunoglobulins and recovered completely after 6 months.

Our clinical experience suggests that sometimes the clinical differences between a bilateral form of NA and a pharyngealbrachial-cervical variant of GBS can be modest, and some patients might be classified either as NA or GBS (see e.g., case 3 of ref. 18).

There are some limitations to our study. First is the issue of case ascertainment bias because our study population represents only a limited proportion of all acute HEV-infected cases. Only a minority of patients with HEV develop symptoms or are detected through an elevated serum aminotransferase level, and most infections are never diagnosed. Moreover, because the referral to the Neurocenter was based on the treating physician's decision, it cannot be excluded that neurologic cases with minor symptoms were missed. Second, our study population mostly included immunocompetent patients in the acute phase of $\mathrm{HEV}$ infection, and we did not focus on chronic cases of $\mathrm{HEV}$ infection. The frequency and the clinical features of neurologic complications in immunosuppressed HEV-infected cases (e.g., transplant recipients) could be different from what we observed, yet 1 study showed that neurologic injury was less common in immunosuppressed patients. ${ }^{22}$ Finally, our observations should be confirmed in different geographical regions. The clustered distribution and high number of NA cases observed might be explained by viral factors such as a special neurotropism. Of note, the viral strain most frequently isolated in Switzerland (3s) appears to be unique, ${ }^{41,42}$ but correlations between viral strains and clinical symptoms are currently lacking, and larger collaborative studies are underway in Europe (e.g., HEVnet, rivm.nl/en/ hevnet) to address this issue.

In conclusion, neurologic symptoms occurred in approximately one-third of documented acute HEV cases and consisted of NA and myalgia. HEV-NA seems to occur more frequently in men and was bilateral in two-thirds of the cases. Larger prospective epidemiologic studies on the potential role of $\mathrm{HEV}$ as a trigger of (neurologic) autoimmunity ${ }^{43}$ and randomized-controlled trials on the treatment of HEV-NA are warranted.

\section{Acknowledgment}

The authors are grateful to Ente Ospedaliero Cantonale, Neuromuscular Research Association of Basel, and BaaschMedicus Stiftung of Zurich for funding support; Klaus Toyka for helpful comments on the manuscript; Swiss Federal Office of Topography (Swisstopo) and Wabern for providing maps and data of figure 2; and Mario Uhr (Synlab Ticino) for collaborating on data collection.

\section{Study funding}

ABREOC 2016 (Ente Ospedaliero Cantonale funding) to PR and CG; Neuromuscular Research Association Basel (NERAB) 2016 to PR; Baasch-Medicus Foundation 2018 to PR.

\section{Disclosure}

All authors report no conflicts of interest to the present project. Go to Neurology.org/NN for full disclosures.

\section{Publication history}

Received by Neurology: Neuroimmunology \& Neuroinflammation September 16, 2019. Accepted in final form October 11, 2019.

\begin{tabular}{|c|c|c|c|}
\hline Authors & Location & Role & Contribution \\
\hline $\begin{array}{l}\text { Paolo } \\
\text { Ripellino, } \\
\text { MD }\end{array}$ & $\begin{array}{l}\text { Neurocenter of } \\
\text { Southern } \\
\text { Switzerland, CH }\end{array}$ & Author & $\begin{array}{l}\text { Design and } \\
\text { conceptualization of } \\
\text { the study, major role } \\
\text { in the acquisition of } \\
\text { data, analysis of the } \\
\text { data, and writing and } \\
\text { revision of the } \\
\text { manuscript }\end{array}$ \\
\hline $\begin{array}{l}\text { Emanuela } \\
\text { Pasi, MSc }\end{array}$ & $\begin{array}{l}\text { Laboratory of } \\
\text { Microbiology EOLAB, } \\
\mathrm{CH}\end{array}$ & Author & $\begin{array}{l}\text { Major role in the } \\
\text { acquisition of data } \\
\text { and analysis of the } \\
\text { data }\end{array}$ \\
\hline
\end{tabular}


Appendix (continued)

\begin{tabular}{|c|c|c|c|}
\hline Authors & Location & Role & Contribution \\
\hline $\begin{array}{l}\text { Giorgia } \\
\text { Melli, MD, } \\
\text { PhD }\end{array}$ & $\begin{array}{l}\text { Neurocenter of } \\
\text { Southern } \\
\text { Switzerland, } \mathrm{CH} ; \\
\text { Faculty of biomedical } \\
\text { Sciences, USI, CH }\end{array}$ & Author & $\begin{array}{l}\text { Acquisition of data } \\
\text { and interpretation } \\
\text { and revision of the } \\
\text { manuscript for } \\
\text { important intellectual } \\
\text { content }\end{array}$ \\
\hline
\end{tabular}

\begin{tabular}{ll}
\hline Claudio & Neurocenter of \\
Staedler, & Southern \\
MD & Switzerland, CH
\end{tabular}

Author Acquisition of data and interpretation and revision of the manuscript for important intellectual content

\begin{tabular}{|c|c|c|c|}
\hline $\begin{array}{l}\text { Monserrat } \\
\text { Fraga, MD }\end{array}$ & $\begin{array}{l}\text { Division of } \\
\text { Gastroenterology } \\
\text { and Hepatology, } \\
\text { Lausanne University } \\
\text { Hospital, CH }\end{array}$ & Author & $\begin{array}{l}\text { Data interpretation } \\
\text { and revision of the } \\
\text { manuscript for } \\
\text { important intellectual } \\
\text { content }\end{array}$ \\
\hline
\end{tabular}

\begin{tabular}{llll}
\hline Darius & Division of & Author & Data interpretation \\
Moradpour, & Gastroenterology & & and revision of the \\
MD & and Hepatology, & mancript for \\
& Lausanne University & important intellectual \\
& Hospital, CH & content
\end{tabular}

\begin{tabular}{|c|c|c|c|}
\hline $\begin{array}{l}\text { Roland } \\
\text { Sahli, MSc, } \\
\text { PhD }\end{array}$ & $\begin{array}{l}\text { Institute of } \\
\text { Microbiology, } \\
\text { Lausanne University } \\
\text { Hospital, CH }\end{array}$ & Author & $\begin{array}{l}\text { Major role in the } \\
\text { acquisition of data } \\
\text { and revision of the } \\
\text { manuscript for } \\
\text { important intellectual } \\
\text { content }\end{array}$ \\
\hline
\end{tabular}

\begin{tabular}{llll}
\hline Vincent & Laboratory of & Author & Major role in the \\
Aubert, & Immunology, \\
MSc, PhD & Lausanne University & & \\
& Hospital, CH & &
\end{tabular}

\begin{tabular}{|c|c|c|c|}
\hline $\begin{array}{l}\text { Gladys } \\
\text { Martinetti, } \\
\text { MSc }\end{array}$ & $\begin{array}{l}\text { Laboratory of } \\
\text { Microbiology EOLAB, } \\
\mathrm{CH}\end{array}$ & Author & $\begin{array}{l}\text { Major role in the } \\
\text { acquisition of data } \\
\text { and analysis of the } \\
\text { data }\end{array}$ \\
\hline
\end{tabular}

MD Hepatology, Hospital acquisition of data of Bellinzona, $\mathrm{CH}$ and revision of the manuscript for important intellectual content

\begin{tabular}{llll}
\hline Enos & Division of Infectious & Author & Data interpretation \\
Bernasconi, & Diseases, Hospital of & and revision of the \\
MD & Lugano, CH & $\begin{array}{l}\text { manuscript for } \\
\text { important intellectual } \\
\text { content }\end{array}$
\end{tabular}

\begin{tabular}{|c|c|c|c|}
\hline $\begin{array}{l}\text { Benedetta } \\
\text { Terziroli- } \\
\text { Beretta } \\
\text { Piccoli, MD }\end{array}$ & $\begin{array}{l}\text { Epatocentro Ticino, } \\
\mathrm{CH}\end{array}$ & Author & $\begin{array}{l}\text { Major role in the } \\
\text { acquisition of data } \\
\text { and revision of the } \\
\text { manuscript for } \\
\text { important intellectual } \\
\text { content }\end{array}$ \\
\hline
\end{tabular}

\begin{tabular}{llll}
\hline $\begin{array}{l}\text { Andreas } \\
\text { Cerny, MD }\end{array}$ & Epatocentro Ticino, & Author & Data interpretation \\
& and revision of the \\
& manuscript for \\
& important intellectual \\
& & content \\
\hline
\end{tabular}

\begin{tabular}{|c|c|c|c|}
\hline $\begin{array}{l}\text { Harry } \\
\text { Dalton, MD, } \\
\text { PhD }\end{array}$ & $\begin{array}{l}\text { Queens Park, } \\
\text { London, UK }\end{array}$ & Author & $\begin{array}{l}\text { Data interpretation } \\
\text { and revision of the } \\
\text { manuscript for } \\
\text { important intellectual } \\
\text { content }\end{array}$ \\
\hline
\end{tabular}

Appendix (continued)

\begin{tabular}{|c|c|c|c|}
\hline Authors & Location & Role & Contribution \\
\hline $\begin{array}{l}\text { Cinzia } \\
\text { Zehnder, } \\
\text { MSc }\end{array}$ & Synlab Ticino, $\mathrm{CH}$ & Author & $\begin{array}{l}\text { Major role in the } \\
\text { acquisition of data }\end{array}$ \\
\hline $\begin{array}{l}\text { Barbara } \\
\text { Mathis, MSc }\end{array}$ & Unilabs Ticino, $\mathrm{CH}$ & Author & $\begin{array}{l}\text { Major role in the } \\
\text { acquisition of data }\end{array}$ \\
\hline $\begin{array}{l}\text { Chiara } \\
\text { Zecca, MD }\end{array}$ & $\begin{array}{l}\text { Neurocenter of } \\
\text { Southern } \\
\text { Switzerland, CH }\end{array}$ & Author & $\begin{array}{l}\text { Revision of the } \\
\text { manuscript for } \\
\text { important intellectual } \\
\text { content }\end{array}$ \\
\hline $\begin{array}{l}\text { Giulio } \\
\text { Disanto, } \\
\text { MD, PhD }\end{array}$ & $\begin{array}{l}\text { Neurocenter of } \\
\text { Southern } \\
\text { Switzerland, CH }\end{array}$ & Author & $\begin{array}{l}\text { Statistical analysis of } \\
\text { data }\end{array}$ \\
\hline $\begin{array}{l}\text { Alain } \\
\text { Kaelin-Lang, } \\
\text { MD, PhD }\end{array}$ & $\begin{array}{l}\text { Neurocenter of } \\
\text { Southern } \\
\text { Switzerland, CH; } \\
\text { Faculty of Biomedical } \\
\text { Sciences, USI, CH }\end{array}$ & Author & $\begin{array}{l}\text { Revision of the } \\
\text { manuscript for } \\
\text { important intellectual } \\
\text { content }\end{array}$ \\
\hline $\begin{array}{l}\text { Claudio } \\
\text { Gobbi, MD }\end{array}$ & $\begin{array}{l}\text { Neurocenter of } \\
\text { Southern } \\
\text { Switzerland, } \mathrm{CH} ; \\
\text { Faculty of Biomedical } \\
\text { Sciences, USI, CH }\end{array}$ & Author & $\begin{array}{l}\text { Design and } \\
\text { coordination of the } \\
\text { study, major role in } \\
\text { the acquisition of } \\
\text { data, and writing and } \\
\text { revision of the } \\
\text { manuscript }\end{array}$ \\
\hline
\end{tabular}

\section{References}

1. Kamar N, Izopet J, Pavio N, et al. Hepatitis E virus infection. Nat Rev Dis Primers 2017;16:17086

2. Capai L, Falchi A, Charrel R. Meta-analysis of human IgG anti-HEV seroprevalence in industrialized countries and a review of literature. Viruses 2019;11:E84.

3. Charrel C, Widmer N, Hotz M, et al. Current hepatitis E virus seroprevalence in Swiss blood donors and apparent decline from 1997 to 2016. Euro Surveill 2018;23: 1700616 .

4. Woolson KL, Forbes A, Vine L, et al. Extra-hepatic manifestations of autochthonous hepatitis E infection. Aliment Pharmacol Ther 2014;40:1282-1291.

5. Kamar N, Marion O, Abravanel F, Izopet J, Dalton HR. Extrahepatic manifestations of hepatitis E virus. Liver Int 2016;36:467-472.

6. Dalton HR, Kamar N, van Eijk JJ, et al. Hepatitis E virus and neurological injury. Nat Rev Neurol 2016;12:77-85.

7. Mclean BN, Gulliver J, Dalton HR. Hepatitis E virus and neurological disorders. Pract Neurol 2017;17:282-288.

8. Dalton P, Norton B, van Eijk J, Dalton HR. Non-traumatic neurological injury and hepatitis E infection. Expert Rev Anti Infect Ther 2018;16:255-257.

9. van Eijk JJ, Madden RG, van der Eijk AA, et al. Neuralgic amyotrophy and hepatitis E virus infection. Neurology 2014;82:498-503.

10. van den Berg B, van der Eijk AA, Pas SD, et al. Guillain-Barré syndrome associated with preceding hepatitis E virus infection. Neurology 2014;82:491-497.

11. Jha AK, Nijhawan S, Nepalia S, Suchismita A. Association of Bell's palsy with hepatitis E virus infection: a rare entity. J Clin Exp Hepatol 2012;2:88-90.

12. Mengel AM, Stenzel W, Meisel A, Büning C. Hepatitis E-induced severe myositis. Muscle Nerve 2016;53:317-320.

13. Kejariwal D, Roy S, Sarkar N. Seizure associated with acute hepatitis E. Neurology 2001;57:1935.

14. Sarkar P, Morgan C, Ijaz S. Transverse myelitis caused by hepatitis E: previously undescribed in adults. BMJ Case Rep 2015;2015:bcr2014209031.

15. Wang $\mathrm{L}, \mathrm{Gao} \mathrm{F}$, Lin $\mathrm{G}$, et al. Association of hepatitis $\mathrm{E}$ virus infection and myasthenia gravis: a pilot study. J Hepatol 2018;68:1318-1320.

16. Geurtsvankessel CH, Islam Z, Mohammad QD, Jacobs BC, Endtz HP, Osterhaus AD. Hepatitis E and Guillain-Barré syndrome. Clin Infect Dis 2013;57:1369-1370.

17. Fukae J, Tsugawa J, Ouma S, Umezu T, Kusunoki S, Tsuboi Y. Guillain-Barré and Miller Fisher syndromes in patients with anti-hepatitis E virus antibody: a hospitalbased survey in Japan. Neurol Sci 2016;37:1849-1851.

18. Stevens O, Claeys KG, Poesen K, Saegeman V, Van Damme P. Diagnostic challenges and clinical characteristics of hepatitis $\mathrm{E}$ virus-associated Guillain-Barré syndrome. JAMA Neurol 2017;1:26-33.

19. Dalton HR, van Eijk JJJ, Cintas P, et al. Hepatitis E virus infection and acute nontraumatic neurological injury: a prospective multicentre study. J Hepatol 2017;67: 925-932. 
20. Kamar N, Bendall RP, Peron JM, et al. Hepatitis E virus and neurologic disorders. Emerg Infect Dis 2011;17:173-179.

21. Perrin HB, Cintas P, Abravanel F, et al. Neurologic disorders in immunocompetent patients with autochthonous acute hepatitis E. Emerg Infect Dis 2015;21:1928-1934

22. Abravanel F, Pique J, Couturier E, et al. Acute hepatitis E in French patients and neurological manifestations. J Infect 2018;77:220-226.

23. Van Eijk JJJ, Groothuis JT, Van Alfen N, et al. Neuralgic amyotrophy: an update on diagnosis, pathophysiology, and treatment. Muscle Nerve 2016;53:337-350.

24. Asbury AK, Cornblath DR. Assessment of current diagnostic criteria for GuillainBarré syndrome. Ann Neurol 1990;27:S21-S24.

25. Fraga M, Doerig C, Moulin H, et al. Hepatitis E virus as a cause of acute hepatitis acquired in Switzerland. Liver Int 2018;38:619-626.

26. Van Eijk JJJ, Dalton HR, Ripellino P, et al. Clinical phenotype and outcome of hepatitis e virus-associated neuralgic amyotrophy. Neurology 2017;89:909-917.

27. van Alfen N, van Engelen BG. The clinical spectrum of neuralgic amyotrophy in 246 cases. Brain 2006; 129:438-450.

28. Watson BV, Rose-Innes A, Engstrom JW, Brown JD. Isolated brachialis wasting: an unusual presentation of neuralgic amyotrophy. Muscle Nerve 2001;24:1699-1702.

29. van Alfen N, Huisman WJ, Overeem S, van Engelen BG, Zwarts MJ. Sensory nerve conduction studies in neuralgic amyotrophy. Am J Phys Med Rehabil 2009;88: 941-946.

30. van Eijk JJJ, van Alfen N, Berrevoets M, van der Wilt GJ, Pillen S, van Engelen BGM. Evaluation of prednisolone treatment in the acute phase of neuralgic amyotrophy: an observational study. J Neurol Neurosurg Psychiatry 2009;80:1120-1124.

31. Bouhassira D, Attal N, Alchaar H, et al. Comparison of pain syndromes associated with nervous or somatic lesions and development of a new neuropathic pain diagnostic questionnaire (DN4). Pain 2005;114:29-36.
32. Martinelli P, Pazzaglia P, Marchiori L, Lugaresi E. Simultaneous occurrence of neuralgic amyotrophy in three members of one family. Eur Neurol 1980;19:316-319.

33. Kovats S. Estrogen receptors regulate innate immune cells and signaling pathways. Cell Immunol 2015;294:63-69.

34. Park HJ, Choi JM. Sex-specific regulation of immune responses by PPARs. Exp Mol Med 2017;49:e364.

35. Nussinovitch U, Shoenfeld Y. The role of gender and organ specific autoimmunity. Autoimmun Rev 2012;11:377-385.

36. Bernsen PL, Wong Chung RE, Vingerhoets HM, Janssen JT. Bilateral neuralgic amyotrophy induced by interferon treatment. Arch Neurol 1988;45:449-451.

37. Silva M, Wicki B, Tsouni $\mathrm{P}$, et al. Hepatitis $\mathrm{E}$ virus infection as a direct cause of neuralgic amyotrophy. Muscle Nerve 2016;54:325-327.

38. Fritz M, Berger B, Schemmerer M, et al. Pathological cerebrospinal fluid findings in patients with neuralgic amyotrophy and acute hepatitis E virus infection. J Infect Dis 2018;217:1897-1901.

39. Ramos-Casals M, Stone JH, Cid MC, Bosch X. The cryoglobulinaemias. Lancet 2012; 379:348-360.

40. Marion O, Abravanel F, Del Bello A, et al. Hepatitis E virus-associated cryoglobulinemia in solid-organ-transplant recipients. Liver Int 2018;38:2178-2189.

41. Kubacki J, Fraefel C, Jermini M, et al. Complete genome sequences of two Swiss hepatitis $\mathrm{E}$ virus isolates from human stool and raw pork sausage. Genome Announc 2017;5:e00888-17.

42. Sahli R, Fraga M, Semela D, Moradpour D, Gouttenoire J. Rabbit HEV in immunosuppressed patients with hepatitis E acquired in Switzerland. J Hepatol 2019;70: 1023-1025.

43. Terziroli Beretta-Piccoli B, Ripellino P, Gobbi C, et al. Autoimmune liver disease serology in acute hepatitis E virus infection. J Autoimmun 2018;94:1-6. 


\section{Neurology \\ Neuroimmunology \& Neuroinflammation}

Neurologic complications of acute hepatitis $\mathbf{E}$ virus infection

Paolo Ripellino, Emanuela Pasi, Giorgia Melli, et al.

Neurol Neuroimmunol Neuroinflamm 2020;7;

DOI 10.1212/NXI.0000000000000643

This information is current as of December 5, 2019

Updated Information \&

Services

References

Subspecialty Collections

Permissions \& Licensing

Reprints including high resolution figures, can be found at:

http://nn.neurology.org/content/7/1/e643.full.html

This article cites 43 articles, 3 of which you can access for free at: http://nn.neurology.org/content/7/1/e643.full.html\#\#ref-list-1

This article, along with others on similar topics, appears in the following collection(s):

Peripheral neuropathy

http://nn.neurology.org//cgi/collection/peripheral_neuropathy

Information about reproducing this article in parts (figures,tables) or in its entirety can be found online at:

http://nn.neurology.org/misc/about.xhtml\#permissions

Information about ordering reprints can be found online: http://nn.neurology.org/misc/addir.xhtml\#reprintsus

Neurol Neuroimmunol Neuroinflamm is an official journal of the American Academy of Neurology.

Published since April 2014, it is an open-access, online-only, continuous publication journal. Copyright

Copyright (C) 2019 The Author(s). Published by Wolters Kluwer Health, Inc. on behalf of the American

Academy of Neurology.. All rights reserved. Online ISSN: 2332-7812.

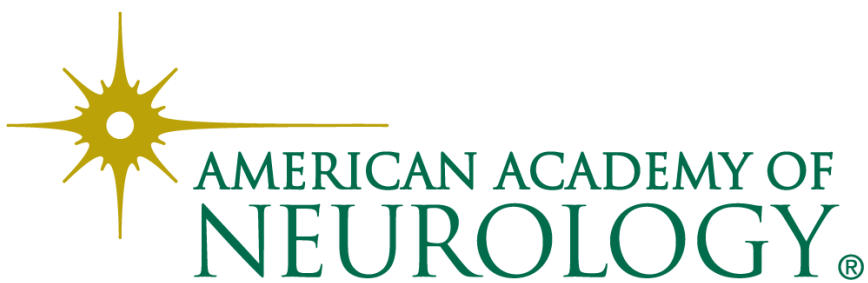

